Journal Club

Editor's Note: These short, critical reviews of recent papers in the Journal, written exclusively by graduate students or postdoctoral fellows, are intended to summarize the important findings of the paper and provide additional insight and commentary. For more information on the format and purpose of the Journal Club, please see http://www.jneurosci.org/misc/ifa_features.shtml.

\title{
Targeted Epigenetic Modulation of Gene Expression in the Brain
}

\author{
(-Evan J. Kyzar ${ }^{1,2}$ and $\odot$ Ritabrata Banerjee ${ }^{1}$ \\ ${ }^{1}$ Center for Alcohol Research in Epigenetics, Department of Psychiatry, and ${ }^{2}$ Medical Scientist Training Program and Graduate Program in Neuroscience, \\ University of Illinois at Chicago, Chicago, Illinois 60612 \\ Review of Heller, Hamilton et al.
}

Epigenetics defines a broad class of changes that occur in the genome without altering the underlying DNA sequence. These changes include covalent chemical modifications to histone terminal tails, direct chemical modification of DNA, regulation of RNA content by noncoding RNAs, and both local and global changes in transcription occurring in response to these and other factors (Jakovcevski and Akbarian, 2012). Research into epigenetics has principally focused on histone and DNA modifications that affect transcription of the underlying DNA either by "opening" the chromatin complex and increasing transcription, or by "closing" the chromatin and decreasing transcription (Jakovcevski and Akbarian, 2012). Histone acetylation, for example, is usually considered a mark of "open chromatin" and thus increased transcription of the underlying DNA, whereas methylation of certain histone lysine residues, such as histone 3 lysine 9 (H3K9) and $\mathrm{H} 3 \mathrm{~K} 27$, is a mark of "closed chromatin" (Kouzarides, 2007; Krishnan et al., 2014). Epigenetic enzymes act to add and remove histone modifications from chromatin in a

Received June 22, 2016; revised July 28, 2016; accepted July 30, 2016.

This work was supported by grants from the National Institute on Alcohol Abuse and Alcoholism, U01AA-019971, and P50AA-022538 (Center for Alcohol Research in Epigenetics). We thank our mentor Dr. Subhash C. Pandey for enthusiastic support and critical discussion.

The authors declare no competing financial interests.

Correspondence should be addressed to Evan J. Kyzar, Department of

Psychiatry, University of Illinois at Chicago, 1601 West Taylor Street (M/C 912), Room 427, Chicago, IL 60612. E-mail: ekyzar2@uic.edu.

DOI:10.1523/JNEUROSCI.1990-16.2016

Copyright $\odot 2016$ the authors $\quad 0270-6474 / 16 / 369283-03 \$ 15.00 / 0$ dynamic and modifiable manner (Jakovcevski and Akbarian, 2012; Krishnan et al., 2014).

Much of the early mechanistic research on epigenetics focused on its role in cancer and development, but the function of epigenetic machinery in the brain has attracted increased attention in recent years (Nestler et al., 2015). Epigenetic processes are implicated in psychiatric disorders, including depression and drug addiction (Jakovcevski and Akbarian, 2012; Nestler et al., 2015; Walker et al., 2015). Additionally, the basic mechanisms underlying epigenetic processes may show subtle but important differences due to brain-specific splice variation and differential isoform expression (e.g., Zibetti et al., 2010). Determining the causal role of epigenetic modifications and the resulting effects on neural systems and behavior requires the use of technologies capable of experimentally inducing specific epigenetic marks at discrete genetic loci. One way to accomplish this involves using zinc finger protein (ZFP) transcription factors, DNA-binding proteins engineered to recognize a specific genetic region, fused with epigenetic effector domains capable of adding or removing particular epigenetic modifications (Maeder et al., 2008). In a recent issue of The Journal of Neuroscience, Heller, Hamilton et al. (2016) used ZFPs to epigenetically modulate expression of a particular gene product involved in stress- and drug-induced behavior.

As cyclin-dependent kinase $5(C d k 5)$ expression in the nucleus accumbens (NAc) is implicated in behavioral responses to both stress and drugs of abuse (Lu et al., 2003; Zhong et al., 2014), Heller, Hamilton et al. (2016) investigated the effect of bidirectional epigenetic modulation of $C d k 5$ expression on cocaine-induced locomotion, cocaine conditioned place preference (CPP), and social defeat stress. Specifically, the authors used a ZFP construct fused to the 65 transcriptional activation domain of nuclear factor $\kappa$-light-chain-enhancer of activated B cells (NF- $\kappa \mathrm{B})(C d k 5-Z F P-p 65)$ that adds activating acetyl groups to chromatin in the $C d k 5$ promoter, along with a separate ZFP construct fused to the histone methyltransferase G9a (Cdk5-ZFP-G9a) to add restrictive methyl groups to $\mathrm{H} 3 \mathrm{~K} 9$ at the $C d k 5$ promoter. These constructs were then transfected into the mouse NAc, where the Cdk5-ZFP-p65 construct increased Cdk5 expression to levels $\sim 1$.4-fold of controls presumably by increasing histone $\mathrm{H} 3 \mathrm{~K} 9 / 14$ acetylation of the $C d k 5$ promoter, and the Cdk5-ZFP-G9a construct decreased Cdk5 expression to levels $\sim 0.5$-fold of controls presumably via increased $\mathrm{H} 3 \mathrm{~K} 9$ dimethylation (H3K9me2).

Increasing $\mathrm{Cdk} 5$ expression in the NAc with Cdk5-ZFP-p65 led to increased cocaine-induced locomotion and reduced susceptibility to social defeat stress while having no effect on cocaine CPP. Conversely, reducing $\mathrm{Cdk} 5$ expression in the NAc with Cdk5-ZFP-G9a resulted in decreased cocaine-induced locomotion that was particularly evident on the third and fourth day of treatment, and also reduced 
cocaine CPP. Cdk5-ZFP-G9a-transfected mice did not show any behavioral alterations after social defeat stress compared with controls.

This research represents a significant step in molecular neuroscience, as the methods used allow investigators to both increase and decrease gene expression within physiologically relevant constraints in discrete brain regions using tools derived from native transcriptional and epigenetic machinery. Although newer technologies are available for inducing epigenetic modifications at specific locations (e.g., dCas9 and CRISPR) (Hsu et al., 2014), Heller, Hamilton et al. (2016) use the older but better characterized technology of ZFPs (Maeder et al., 2008) and performed necessary quality control by measuring mRNA transcripts of genes adjacent to $C d k 5$ and genes with similar motifs to the engineered Cdk5-ZFP constructs, finding no significant alterations in mRNA content. This research builds on a previous finding from the same laboratory group, which showed that engineered ZFPs could bidirectionally modify expression of the Fos $B$ gene and subsequently alter behavior (Heller et al., 2014).

While Heller, Hamilton et al. (2016) succeed in demonstrating that targeted bidirectional epigenetic modification of $C d k 5$ can regulate drug- and stress-related behavior, this paper and potential follow-up studies would be strengthened by measures of either epigenetic modifications ( $\mathrm{H} 3 \mathrm{~K} / 14$ acetylation and $\mathrm{H} 3 \mathrm{~K} 9 \mathrm{me} 2$ ) or $C d k 5$ mRNA expression in the NAc of animals who underwent cocaine administration and/or behavioral tests. In the manuscript, the expression of $C d k 5$ mRNA, as well as the occupancy of H3K9/14 acetylation and $\mathrm{H} 3 \mathrm{~K} 9 \mathrm{me} 2$ in the Cdk5 promoter, was assayed in animals that were not used for behavioral experiments. Complementing behavioral measures with biochemical measures in the same animals would serve to answer two questions. First, does the magnitude of $C d k 5$ epigenetic modulation by ZFPs in the NAc correlate with specific behavioral changes? Measures of $C d k 5$ mRNA expression and/or $\mathrm{H} 3 \mathrm{~K} 9 / 14$ acetylation of the $C d k 5$ promoter region may have elucidated differences in the ability of the viral construct to increase $C d k 5$ promoter acetylation, and subsequently increase expression and possibly influence behavior in individual animals. Correlations between behavior and brain gene expression have proven useful in other research domains. For example, licking and grooming behavior of female rats toward their pups positively correlates with hippocampal glucocorticoid receptor $(G R)$ mRNA in the pups in young adulthood (van Hasselt et al., 2012), and GR expression in the hippocampus is controlled by epigenetic factors, such as DNA methylation, and responds to stressful stimuli (Turecki and Meaney, 2016).

Second, and perhaps most importantly, does the response to cocaine differ between animals injected with a $C d k 5$-ZFP construct in the NAc and control animals? Because cocaine-induced locomotion was measured across multiple days and multiple injections of cocaine (Heller, Hamilton et al., 2016), it is possible that repeated exposure to cocaine differentially altered the chromatin in the $C d k 5$ promoter of virus-transfected animals versus controls. This effect can be envisioned as a chromatin $\times$ drug interaction, where the response to cocaine possibly depends on the existing epigenetic state of the $C d k 5$ promoter. In a previous study using ZFPs targeted to FosB, the same laboratory group performed experiments that addressed these questions by measuring the binding of transcription factors to the Fos $B$ promoter after repeated cocaine exposure in animals injected with FosB-ZFP-G9a in the $\mathrm{NAc}$ and controls, finding that cocaine increased phospo-cAMP response element binding protein occupancy in the FosB promoter in control animals but not in FosBZFP-G9a rats (Heller et al., 2014).

Notably, animals injected with Cdk5ZFP-G9a were given $15 \mathrm{mg} / \mathrm{kg}$ of cocaine on 4 consecutive days during the cocaineinduced locomotion assay (Heller, Hamilton et al., 2016), but the decreased cocaineinduced locomotion in the Cdk5-ZFP-G9a group did not become apparent until days 3 and 4 of the assay. Repeated cocaine exposure alters epigenetic architecture in the $C d k 5$ promoter by increasing deposition of activating acetyl groups (Kumar et al., 2005). One possibility here is that the presence of $\mathrm{H} 3 \mathrm{~K} 9 \mathrm{me} 2$ on the chromatin sterically hinders the addition of acetyl groups to the same residue, or that acetyl groups are added but rapidly removed and replaced by repressive methylation via $C d k 5-Z F P-G 9 a$.

Interestingly, $\mathrm{H} 3 \mathrm{~K} 9 \mathrm{me} 2$ occupancy shows dynamic temporal regulation at neuronal activity-regulated genes, such as activity-regulation cytoskeletal-associated protein $(A r c)$, where this epigenetic mark is initially decreased by neuronal activity before undergoing a compensatory increase that depends on the presence of other chromatin modifications (Oey et al., 2015). H3K9me2 occupancy also displays differential age-dependent regulation at the brain-derived neurotrophic factor $(B d n f)$ promoter IV in the hippocampus following early-life stress (Suri et al., 2013), and epige- netic regulation of this promoter site by both histone and DNA methylation is implicated in the response to stress and drugs of abuse (Tsankova et al., 2006; Kyzar et al., 2016; Tian et al., 2016). Thus, measuring H3K9me2 and/or H3K9/14ac after cocaine exposure in animals injected with ZFP constructs in the NAc has the potential to increase our overall knowledge of epigenetic residue interactions and how these epigenetic marks react to drugs of abuse. Exploring the intricacies of chromatin complex formation and modification may also lead to the discovery of novel epigenetic mechanisms in the brain.

The recent paper by Heller, Hamilton et al. (2016) opens up new and increasingly important lines of investigation in the field of neuroepigenetics. Researchers are now able to modify chromatin at distinct genomic sites with targeted efficacy and the ability to change behavioral output. As this field continues to mature, future work should continue to pioneer tools, such as epigenome engineering, to increase our understanding of the basic molecular function of neurons and neural circuits.

\section{References}

Heller EA, Cates HM, Peña CJ, Sun H, Shao N, Feng J, Golden SA, Herman JP, Walsh JJ, MazeiRobison M, Ferguson D, Knight S, Gerber MA, Nievera C, Han MH, Russo SJ, Tamminga CS, Neve RL, Shen L, Zhang HS, et al (2014) Locus-specific epigenetic remodeling controls addiction- and depression-related behaviors. Nat Neurosci 17:1720-1727. CrossRef Medline Heller EA, Hamilton PJ, Burek DD, Lombroso SI, Peña CJ, Neve RL, Nestler EJ (2016) Targeted epigenetic remodeling of the $C d k 5$ gene in nucleus accumbens regulates cocaine- and stress-evoked behavior. J Neurosci 36:46904697. CrossRef Medline

Hsu PD, Lander ES, Zhang F (2014) Development and applications of CRISPR-Cas9 for genome engineering. Cell 157:1262-1278. CrossRef Medline

Jakovcevski M, Akbarian S (2012) Epigenetic mechanisms in neurological disease. Nat Med 18:1194-1204. CrossRef Medline

Kouzarides T (2007) Chromatin modifications and their function. Cell 128:693-705. CrossRef Medline

Krishnan HR, Sakharkar AJ, Teppen TL, Berkel TD, Pandey SC (2014) The epigenetic landscape of alcoholism. Int Rev Neurobiol 115: 75-116. CrossRef Medline

Kumar A, Choi KH, Renthal W, Tsankova NM, Theobald DE, Truong HT, Russo SJ, Laplant Q, Sasaki TS, Whistler KN, Neve RL, Self DW, Nestler EJ (2005) Chromatin remodeling is a key mechanism underlying cocaine-induced plasticity in striatum. Neuron 48:303-314. CrossRef Medline

Kyzar EJ, Zhang H, Sakharkar AJ, Pandey SC (2016) Adolescent alcohol exposure alters lysine demethylase 1 (LSD1) expression and 
histone methylation in the amygdala during adulthood. Addict Biol. Advance online publication. Retrieved May 15, 2016. doi: 10.1111/ adb.12404. CrossRef Medline

Lu L, Grimm JW, Shaham Y, Hope BT (2003) Molecular neuroadaptations in the accumbens and ventral tegmental area during the first 90 days of forced abstinence from cocaine self-administration in rats. J Neurochem 85: 1604-1613. CrossRef Medline

Maeder ML, Thibodeau-Beganny S, Osiak A, Wright DA, Anthony RM, Eichtinger M, Jiang T, Foley JE, Winfrey RJ, Townsend JA, UngerWallace E, Sander JD, Müller-Lerch F, Fu F, Pearlberg J, Göbel C, Dassie JP, Pruett-Miller SM, Porteus MH, Sgroi DC, et al (2008) Rapid "open source" engineering of customized zinc-finger nucleases for highly efficient gene modification. Mol Cell 31:294-301. CrossRef Medline

Nestler EJ, Peña CJ, Kundakovic M, Mitchell A, Akbarian S (2015) Epigenetic basis of mental illness. Neuroscientist. Advance online publication. Retrieved Oct. 8, 2016. doi: $10.1177 / 1073858415608147$. CrossRef Medline
Oey NE, Leung HW, Ezhilarasan R, Zhou L, Beuerman RW, VanDongen HM, VanDongen AM (2015) A neuronal activity-dependant dual function chromatin-modifying complex regulation Arc expression. eNeuro 2:piiENEURO.0020-14.2015. CrossRef Medline

Suri D, Veenit V, Sarkar A, Thiagarajan D, Kumar A, Nestler EJ, Galande S, Vaidya VA (2013) Early stress evokes age-dependent biphasic changes in hippocampal neurogenesis, BDNF expression, and cognition. Biol Psychiatry 73: 658-666. CrossRef Medline

Tian W, Wang J, Zhang K, Teng H, Li C, Szyf M, Sun ZS, Zhao M (2016) Demethylation of c-MYB binding site mediates upregulation of Bdnf IV in cocaine-conditioned place preference. Sci Rep 6:22087. CrossRef Medline

Tsankova NM, Berton O, Renthal W, Kumar A, Neve RL, Nestler EJ (2006) Sustained hippocampal chromatin regulation in a mouse model of depression and antidepressant action. Nat Neurosci 9:519-525. CrossRef Medline

Turecki G, Meaney MJ (2016) Effects of the social environment and stress on glucocorticoid receptor gene methylation: a systematic review. Biol Psychiatry 79:87-96. CrossRef Medline van Hasselt FN, Cornelisse S, Zhang TY, Meaney MJ, Velzing EH, Krugers HJ, Joëls M (2012) Adult hippocampal glucocorticoid receptor expression and dentate synaptic plasticity correlate with maternal care received by individuals early in life. Hippocampus 22:255-266. CrossRef Medline

Walker DM, Cates HM, Heller EA, Nestler EJ (2015) Regulation of chromatin states by drugs of abuse. Curr Opin Neurobiol 30: 112-121. CrossRef Medline

Zhong P, Liu X, Zhang Z, Hu Y, Liu SJ, LezamaRuiz M, Joksimovic M, Liu QS (2014) Cyclin-dependent kinase 5 in the ventral tegmental area regulates depression-related behaviors. J Neurosci 34:6352-6366. CrossRef Medline

Zibetti C, Adamo A, Binda C, Forneris F, Toffolo E, Verpelli C, Ginelli E, Mattevi A, Sala C, Battaglioli E (2010) Alternative splicing of the histone demethylase LSD1/KDM1 contributes to the modulation of neurite morphogenesis in the mammalian nervous system. J Neurosci 30:2521-2532. CrossRef Medline 